\title{
ANALISIS CONTENT BUKU AJAR BAHASA ARAB (PENDEKATAN SAINTIFIK KURIKULUM 2013) KELAS I MADRASAH IBTIDAIYAH TERBITAN KEMENTRIAN AGAMA REPUBLIK INDONESIA 2014
}

\author{
Nurul Hadi \\ IAIN Pamekasan \\ Email: nurulhadi@gmail.com
}

\begin{abstract}
This research is aimed to reveal the appropriateness of Arabic textbook for the first grade of Islamic Elementary School/ Madrasah Ibtidaiyah (MI) published by Ministry of Religious Affairs of Indonesia in 2014 by using scientific approach. In analyzing this textbook, the researcher used library research and analyzed it by using content analysis and utilizing the theory of Arabic textbook arrangement by Nashir al-Ghali, besides that, the researcher also analyzed it by considering four aspects of Arabic textbook arrangement by Mackey which involves: selection, gradation, presentation, and repetition. And to identify either the textbook is appropriate or not to use based on 2013 curriculum standard, therefore, the researcher used regulation of Ministry of Religious Affairs (PMA) of Indonesia, Number: 0912 years 2013 about 2013 curriculum for madrasah of Islamic education and Arabic subjects as references. The result of the analysis on Arabic textbook with scientific approach of 2013 curriculum for the first grade of Islamic elementary school (Madrasah Ibtidaiyah) published by Ministry of Religious Affairs in 2014 showed that it was relevant and appropriate to be used to the students at the first grade of elementary level (Madrasah level) as material source that can support to achieve the goals of Arabic learning.
\end{abstract}

Key words: Content analysis; text book; Arabic language; scientific approach

\section{A. PENDAHULUAN}

Perubahan kurikulum untuk sekolah dan madrasah menjadi isu paling krusial akhir-akhir ini. Kurikulum Tingkat Satuan Pembelajaran (KTSP) yang sudah mulai diterapakan sejak tahun 2006 (R. Indonesia, t.t.) dikonversi ke dalam kurikulum 2013 (K13) dengan beberapa perbedaan yang mendasar (Pendidikan, 2013, hlm. 81; Pendidikan \& Nomor, t.t.). Perubahan kurikulum ini terus menjadi pusat kebingungan banyak sekolah maupun madrasah dalam penerapannya.

Untuk mempersiapkan kesempurnaan K-13 ini, pelbagai upaya pemerintah melalui Kementerian Pendidikan dan Kebudayaan Republik Indonesia (Kemendikbud RI) telah dilakukan. Mulai dari sosialisasi, pelatihan dan penyiapan perangkat pembelajaran. Karena untuk dapat menerapkan kebijakan baru dalam kurikulum pendidikan, tentu saja harus diawali dengan pemahaman yang menyeluruh dari semua elemen yang terkait, seperti kepala sekolah, guru, pengawas dan stakeholders lainnya.

Tidak berhenti di situ, penerapan kurikulum baru juga harus diikuti dengan ketersediaan materi pembelajaran (bahan ajar). Dalam menyiapkan bahan ajar, seorang guru dituntut untuk memahami secara mendetail tujuan pembelajaran yang sudah 
ditetapkan oleh pemerintah dalam bentuk Kompetensi Inti dan Kompetensi Dasar (KI \& KD). Setelah itu, guru juga harus mengetahui Ruang Lingkup Materi yang tertuang dalam Peraturan Menteri Agama (PMA), Nomor: 0912 Tahun 2013 tentang Kurikulum Madrasah 2013. PMA ini menjadi pedoman penting untuk pengembangan materi bahasa Arab di semua tingkatan madrasah, mulai dari MI, MTs dan MA. Oleh karena itu, Guru Bahasa Arab wajib mengetahui dan mengikuti PMA ini dalam pemberian materi ajar di semua tingkatan. Baru kemudian mulai menyusun bahan ajar yang relevan dengan kurikulum dan sesuai dengan kebutuhan peserta didik.

Namun demikian, sejak diberlakukannya kurikulum 2013 di madrasah di lingkungan Kementerian Agama sampai sekarang masih sedikit buku pelajaran yang dapat diakses oleh guru-guru di Madrasah. Sedangkan ketersediaan buku pelajaran merupakan indikator penting bahwa kurikulum tersebut benar-benar diterapkan sesuai konsep dan filosopi yang diharapkan. Sementara buku pelajaran yang dipersiapkan oleh Kementerian Agama Republik Indonesia sendiri masih belum beredar luas. Kalaupun sudah beredar, tetapi secara kualitas masih diragukan.

Ketersedian buku yang layak dan sesuai dengan kaidah penyusunan bahan ajar (buku pelajaran) tentu akan membantu kesuksesan penerapan kurikulum. Buku teks pelajaran adalah kendaraan utama penyampaian materi kurikulum ke hadapan siswa. Karena peranannya yang demikian sentral itu, maka kemajuan dan kemunduran pendidikan suatu bangsa dapat dilacak dari tinggi rendahnya mutu buku teks yang dibaca oleh anak didik (Mujib, 2013).

Kehadiran buku yang diterbitkan oleh Kementerian Agama RI yang sejatinya dapat memenuhi kebutuhan guru di sekolah-sekolah atau madrasah-madrasah justru disinyalir kurang memenuhi harapan. Hal itu, setidaknya telah ditemukan adanya beberapa kelemahan --yang sekilas telah peneliti lihat-- dalam Buku Ajar Bahasa Arab (Pendekatan Saintifik Kurikulum 2013) untuk tingkat Madrasah Aliyah Terbitan Kementerian Agama Republik Indonesia 2014.

Maka dengan demikian, peneliti melihat pentingnya untuk melakukan penelitian yang lebih serius dan mendalam terhadap buku tersebut. Terutama buku ajar Madrasah Ibtidaiyah, karena madrasah ini menjadi pondasi awal pembelajaran Bahasa Arab berbasis sekolah. Inilah yang menjadi titik awal ketertarikan peneliti untuk melakukan penelitian terhadap isi (content analysis) Buku Ajar Bahasa Arab (Pendekatan Saintifik Kurikulum 2013) Terbitan Kementerian Agama Republik Indonesia 2014. Mengingat kedudukan buku pelajaran yang diterbitkan oleh Kementerian Agama sangat signifikan, bahkan terkadang menjadi barometer buku-buku pelajaran yang senada berikutnya. Oleh karena itu, buku pelajaran yang diterbitkan oleh Kementerian Agama perlu adanya jaminan mutu (warranty of quality). Sehingga, baik guru maupun masyarakat dapat -dengan penuh keyakinan-- menerapkan buku itu dengan baik.

\section{B. METODE PENELITIAN}

Penelitian ini menggunakan pendekatan kualitatif. Pendekatan kualitatif adalah penelitian yang lebih menekankan pada pengumpulan data yang bersifat kualitatif (tidak berbentuk angka) dan menggunakan analisis kualititatif dalam pemaparan data, analisis data, dan pengambilan kesimpulan (Lexy, 2002).

Sedangkan jenis penelitian kualitatif yang diterapkan dalam penelitian ini adalah penelitian kepustakaan (library research). Yaitu, jenis penelitian yang dilakukan dengan 
cara mengumpulkan data-data yang bersumber dari buku, jurnal, kitab, artikel, dan tulisan-tulisan tertentu (Pohan, 2007).

Metode yang digunakan peneliti dalam pengumpulan data adalah metode dokumentasi. Yaitu metode pengumpulan data tentang hal-hal yang terkait dengan penelitian dari sumber berupa catatan, transkip, buku, majalah, skripsi, tesis, disertasi, surat kabar, majalah, laporan penelitian, dan lainnya (Pd, 2010).

Adapun sumber data dalam penelitian ini adalah sumber primer dan skunder. Sumber primer dalam penelitian ini adalah Buku Guru Bahasa Arab Durus al-Lughah alrabiyah (Pendekatan Saintifik Kurikulum 2013) Terbitan Kementerian Agama Republik Indonesia 2014.

Sedangkan sumber sekunder yang digunakan peneliti untuk menganalisis buku guru Bahasa Arab Durus al-Lughah al-Arabiyah adalah buku-buku dan sumber-sumber yang terkait dengan penelitian ini, seperti Buku Usus I'dadu al-Kutub al-Ta'limiyah li Ghairi al-Nathiqina bi al-Arabiyah, karya Dr. Nashir Abdullah al-Ghali dan Dr. Abdul Hamid Abdullah.

Dalam menganalisis data, peneliti mengacu pada empat aspek analisis pengajaran bahasa menurut teori Mackey, yang meliputi: seleksi, gradasi, presentasi dan repetisi. Dan untuk mengetahui apakah buku tersebut sudah layak untuk digunakan sesuai tuntutan kurikulum 2013, maka peneliti menggunakan analisis isi buku dengan Peraturan Menteri Agama (PMA) Republik Indonesia Nomor: 0912 Tahun 2013 Tentang Kurikulum Madrasah 2013 Mata Pelajaran Pendidikan Agama Islam dan Bahasa Arab.

\section{BUKU AJAR BAHASA ARAB (PENDEKATAN SAINTIFIK KURIKULUM 2013) KELAS I MADRASAH IBTIDAIYAH TERBITAN KEMENTRIAN AGAMA REPUBLIK INDONESIA 2014}

\section{Identitas buku}

Sebagaimana disebutkan pada cover, Buku Bahasa Arab pendekatan saintifik Kurikulum 2013 ini dipersiapkan Pemerintah dalam rangka implementasi Kurikulum 2013. Buku ini disusun dan ditelaah oleh berbagai pihak di bawah koordinasi Kementerian Agama, dan dipergunakan dalam penerapan Kurikulum 2013. Buku ini merupakan "dokumen hidup" yang senantiasa diperbaiki, diperbaharui, dan dimutakhirkan sesuai dengan dinamika perubahan zaman.

Buku yang diterbitkan pada tahun 2014 ini terdiri dari dua buku untuk masingmasing jilid/kelas: untuk guru dan untuk sisiwa. Ukuran buku guru sama dengan buku siswa, yaitu 17,6 x 25 (B5). Sedangkan ketebalan ada sedikit perbedaan, buku guru terdiri dari 38 halaman ditambah xxii halaman pengantar, sedangkan buku untuk siswa ada 62 halaman plus $\mathrm{x}$ halaman pengantar.

Buku ini sudah terdaftar dalam ISBN (International Standard Book Number) baik semua jilid maupun masing-masing jilid. Adapun ISBN untuk semua jilid buku guru adalah ISBN 978-979-8446-48-1 sementara untuk jilid 1 buku guru ISBN 978-979-844649-8. ISBN ini ternyata berbeda dengan buku siswa, yaitu ISBN 978-979-8446-43-6 (untuk nomor jilid lengkap) dan ISBN 978-979-8446-44-3. Setelah peneliti melakukan penelusuran ISBN melalui website: isbn.perpusnas.go.id semua ISBN tersebut adalah valid.

Buku ini berasal dari beberapa naskah yang ditelaah oleh Fuad Thohari, sedangkan contributor naskah buku ini adalah Abdi Pemi Karyanto, Abdul Aziz, dan 
Mugi Nugraha. Sementara penyedia penerbitan adalah Direktorat Pendidikan Madrasah Direktorat Pendidikan Islam Kementerian Agama Republik Indonesia (Kementerian Agama Republik Indonesia, 2014).

\section{Latar belakang penyusunan buku}

Latar belakang penulisan buku ini dijelaskan oleh direktur jenderal pendidikan Islam, Nur Syam dalam kata pengantarnya sebagai berikut:

"Sebagai panduan dalam pelaksanaan Kurikulum 2013 di Madrasah, Kementerian Agama RI telah menyiapkan model Silabus Pembelajaran PAI di Madrasah dan menerbitkan Buku Pegangan Siswa dan Buku Pedoman Guru. Kehadiran buku bagi siswa ataupun guru menjadi kebutuhan pokok dalam menerapkan Kurikulum 2013 di Madrasah.

Sebagaimana kaidah Ushul Fikih, mālā yatimmu al-wājibu illā bihī fahuwa wājibun, (suatu kewajiban tidak menjadi sempurna tanpa adanya hal lain yang menjadi pendukungnya, maka hal lain tersebut menjadi wajib). Atau menurut kaidah Ushul Fikih lainnya, yaitu al-amru bi asy-syai'i amrun bi wasāilihī (perintah untuk melakukan sesuatu berarti juga perintah untuk menyediakan sarananya).

Perintah menuntut ilmu berarti juga mengandung perintah untuk menyedikan sarana pendukungnya, salah satu di antaranya Buku Ajar. Karena itu, Buku Pedoman Guru dan Buku Pegangan Siswa ini disusun dengan Pendekatan Saintifik, yang terangkum dalam proses mengamati, menanya, mengeksplorasi, mengasosiasi dan mengkomunkasikan.

Keberadaan Buku Ajar dalam penerapan Kurikulum 2013 di Madrasah menjadi sangat penting dan menentukan, karena dengan Buku Ajar, siswa ataupun guru dapat menggali nilai-nilai secara mandiri, mencari dan menemukan inspirasi, aspirasi, motivasi, atau bahkan dengan buku akan dapat menumbuhkan semangat berinovasi dan berkreasi yang bermanfaat bagi masa depan."

Dengan demikian, buku ini adalah buku baru yang disesuaikan dengan konsep kurikulum 2013 dengan pendekatan saintifik.

\section{Tujuan penyusunan buku}

Dalam petunjuk umum penggunaan buku ajar ini, dijelaskan bahwa Pelajaran Bahasa Arab pada kelas I MI diarahkan secara bertahap untuk mendorong, membimbing, mengembangkan, dan membina kemampuan serta menumbuhkan sikap positif terhadap bahasa Arab, yaitu kemampuan yang terbatas pada kemampuan menyimak dan menirukan, serta penguasaan kosakata (mufradat) untuk berkomunikasi secara lisan, sesuai dengan cara berfikir dan kemampuan kebahasaan siswa, tidak bertujuan mengembangkan keterampilan membaca dalam pengertian pemahaman, dan menulis dalam pengertian menyusun kalimat (insya). Dengan kata lain, tujuan afektiflah yang dikedepankan, lalu tujuan psikomotorik, kemudian tujuan kognitif yang mendukung teruwjudnya tujuan afektif.

Sebagai bagian dari kurikulum 2013 yang menekankan pentingnya keseimbangan kompetensi sikap, pengetahuan, dan keterampilan, maka pembelajaran bahasa Arab dituntut dapat berkonstribusi dalam membentuk karakter siswa dengan menginternalisasikan nilai-nilai keislaman, budaya Timur Tengah dan budaya universal kontemporer yang tidak bertentangan dengan Islam. 
Sehingga tujuan dari jelas mengacu kepada konsep dasar kurikulum 2013, yang bukan hanya menekankan pada sisi kognitif tapi juga harus dapat membentuk sikap religiusitas siswa dan sikap sosial siswa sebagaimana terangkum dalam kompetensi inti.

\section{Format Penyususnan Buku}

Materi pelajaran bahasa Arab di kelas I ini masih terbatas pada 'menyebutkan' apa nama Arab benda-benda, hal-hal yang terkait lingkungan sekitar dan kegiatankegiatan yang bisaa disaksikan atau dilakukan secara rutin oleh siswa MI.

Adapun struktur kalimat, tidak ada yang sengaja diprogramkan dan dipelajari secara khusus. Suatu struktur kalimat -jika digunakan- semata-mata untuk tujuan mengomunikasikan kosakata (mufradat) yang dipelajari.

Buku pelajaran untuk kelas I ini meliputi delapan dars. Empat dars pada semester ganjil dan empat dars lainnya pada semester genap. Setiap semester diakhiri dengan sebagai bahan latihan atau evaluasi terhadap prestasi siswa dalam menguasai materi pelajaran pada semester yang bersangkutan.

Setiap dars terdiri atas empat komponen, yaitu: membaca kosakata, membaca gambar, menyimak ujaran, dan latihan (tadribat). Adapun langkah-langkah dalam melakukan pembelajaran dijelaskan dalam buku guru sebagai berikut:

Ayo Membaca!

Ayo Membaca Gambar!

Ayo Menyimak!

Ayo Latihan!

Yang dimaksud dengan Ayo Membaca! adalah: Membaca mufradat meliputi dua langkah, yaitu: (1.) (Sebaiknya daftar mufradat dimaksud, ditulis di papan tulis)/atau melalui slide, guru membacakan setiap mufradat lalu ditirukan oleh siswa secara kelompok atau bersama-sama. Kegiatan ini dilakukan lebih dari satu kali, sehingga siswa dapat melafalkannya dengan makhraj serta panjang pendek yang benar. (2.) Guru meminta beberapa orang siswa membaca secara perorangan mufradat satu persatu, di papan tulis atau di buku masing-masing. 'Campur tangan' guru dilakukan jika terdapat kesalahan bacaan siswa, baik dalam makhraj atau panjang pendek bacaan. Untuk pemantapan, penunjukkan mufradat dapat dilakukan secara acak, tidak berurutan seperti semula.

Maksud membaca di sini adalah 'melafalkan' tiap mufradat. Kemudian sejalan dengan belajar membaca huruf Arab yang dilakukan secara bertahap.

Sedangkan yang dimaksud dengan Ayo Membaca Gambar! Adalah guru menjelaskan makna atau arti tiap mufradat dengan menggunakan gambar. Yaitu gambar yang tertera pada buku pelajaran, atau gambar tersebut difotokopi, lalu dilem pada kartu yang terbuat dari karton dengan ukuran (misalnya $12 \times 15 \mathrm{~cm}$ ), sehingga akan terlihat jelas oleh seluruh siswa ketika ditampilkan/diperlihatkan oleh guru di depan kelas.

Sementara Ayo Menyimak! Maksudnya adalah Materi menyimak adalah mufradat yang telah dikenalkan, dan sebaiknya disiapkan di papan tulis, dengan langkahlangkah sebagai berikut: (1.) Guru meminta seorang siswa untuk tampil di depan kelas, berdiri di kiri papan tulis, dengan memegang alat penunjuk; (2.) Guru mengucapkan satu mufradat, sementara siswa yang bersangkutan (dan siswa seluruhnya) mendengarkan ucapan guru dengan penuh perhatian; (3.) Siswa menunjuk kata di papan tulis yang sesuai dengan ucapan yang diperdengarkan tadi. 
Tahap akhirnya adalah Ayo Latihan! dalam hal ini adalah latihan pada umumnya dilakukan dalam bentuk tanya jawab sederhana dalam rangka mengkomunikasikan mufradat dars yang bersangkutan. Dengan menggunakan gambar, tadribat bertujuan semata-mata untuk memantapkan pemahaman mufradat, tidak bertujuan untuk melatihkan struktur (Qawaid).

\section{Kesesuaian Buku dengan Konsep K-13}

Untuk menganalisis kesesuaian content buku ajar Bahasa Arab (Pendekatan Saintifik Kurikulum 2013) Kelas I Madrasah Ibtidaiyah terbitan Kementerian Agama Republik Indonesia tahun 2014 ini, peneliti menerapkan teori penyusunan buku pelajaran Bahasa Arab yang dikemukakan oleh M. Abdul Hamid dalam buku "Pembelajaran Bahasa Arab: Pendekatan, Metode, Strategi, Materi dan Media". Selain itu, analisis content ini dikomparasikan dengan konten muatan kurikulum 2013 (K-13) sebagai landasan formal kurikulum pemerintah yang mengacu pada Peraturan Menteri Agama (PMA) Nomor 0912 Tahun 2013.

Dari aspek asas penyusunan buku pelajaran, peneliti menggunakan teori Nasir Abdullah Al-Ghali dan Abdul Hamid Abdullah dalam buku "Usus I'dad al-Kutub alTa'limiyah li Ghairi al-Nathiqina bi al-Arabiyah".

Sedangkan khusus dalam analisis kesesuaian content buku pelajaran Bahasa Arab ini dalam hal "seleksi, gradasi, presentasi dan repetisi", maka peneliti menggunakan teori Mackey yang dipaparkan oleh Nurhadi dalam buku "Tata Bahasa Pendidikan (Landasan Penyusunan Buku Pelajaran Bahasa)".

Adapun factor-faktor yang harus diperhatikan dalam buku pelajaran bahasa Arab menurut M. Abdul Hamid adalah sebagai berikut:

\section{a) Isi Buku}

Ada tiga indicator yang harus diperhatikan dalam melihat kelayakan isi pada buku pelajaran: (1) kesesuaian materi dengan KI dan KD pada kurikulum; (2) keakuratan materi; (3) materi pendukung pelajaran (Muslich, 2010).

Ketiga indicator ini akan peneliti uraikan dalam sub pembahasan tersendiri di bawah ini. Namun demikian, secara spesifik telah dicantumkan dalam judul buku ini dan dijelaskan pula dalam kata pengantarnya bahwa buku ini mengacu pada konsep dasar Kurikulum 2013 (K-13). Statmen itu, kemudian dibuktikan dengan daftar isi tema-tema yang akan dimuat dalam buku tersebut memang mengacu kepada tema-tema yang terdapat dalam PMA nomor 0912 tahun 2013.

Sedangkan validitas isi dari buku tersebut dapat dilihat dari pilihan tema yang dipaparkan dalam setiap semesternya. Tema-tema pilihan tersebut dianggap valid apabila sesuai dengan tuntutan Kompetensi Inti (KI) dan Kompetensi Dasar (KD) yang termuat dalam PMA 0912 tahun 2013.

\section{b) Ketepatan Cakupan}

Adapun tema-tema yang dijabarkan dalam buku Bahasa Arab yang dimaksud tergambar dalam tabel berikut: 

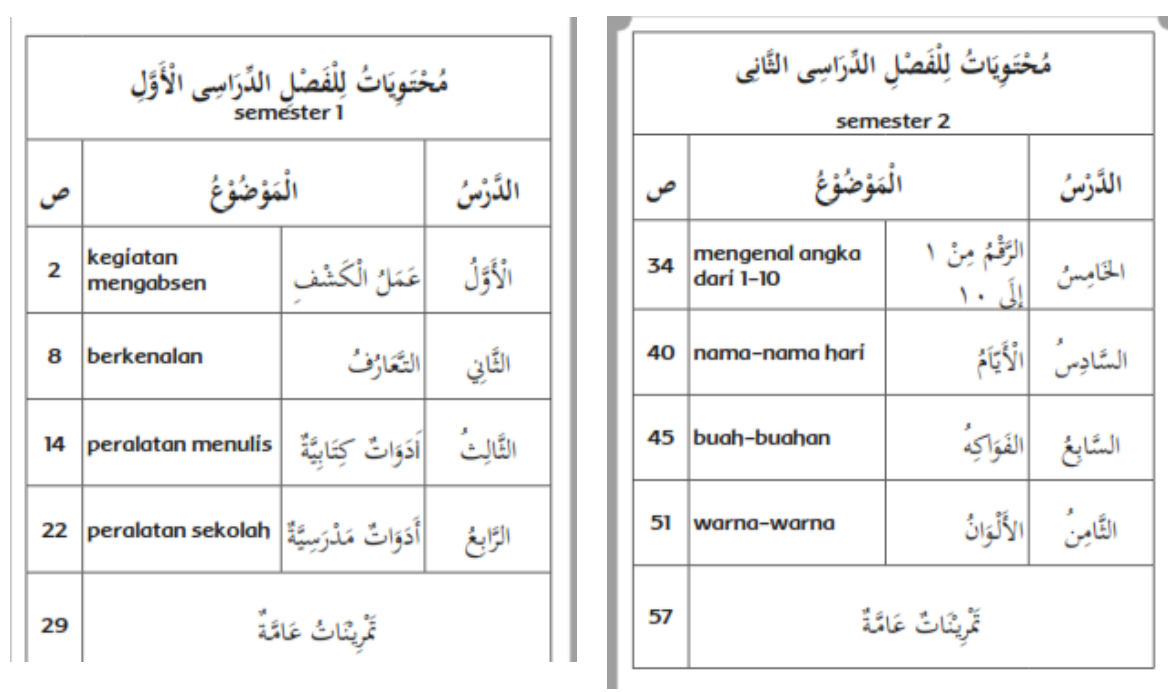

Dari cakupan tema yang ditampilkan dalam daftar isi di atas, terlihat dengan jelas bahwa tema-tema pilihan yang dipaparkan dalam buku Bahasa Arab terbitan Kementerian Agama tahun 2014 ini sesuai dengan muatan K-13.

Dengan artian, tuntutan tematik yang diinginkan K-13 untuk materi Bahasa Arab kelai I Madrasah Ibtidaiyah untuk semester I berupa:

(1) ('amalu al-kasyfi) yaitu kegiatan mengabsen siswa menggunakan bahasa Arab;

(2) التعارف (al-ta'aruf) yaitu perkenalan dalam bahasa Arab;

(3) الأدوات الكتابية (al-adawat al-kitabiyah) yaitu pengenalan alat-alat menulis dalam bahasa Arab;

(4) الأدوات المدرسية (al-adawat al-madrasiyah) yaitu pengenalan alat-alat sekolah dalam bahasa Arab

Sedangkan tema-tema materi Bahasa Arab untuk semester II pada kelas I Madrasah Ibtidaiyah berupa:

(1) الرقم من l (al-raqmu min 1 ila 10) yaitu mengenal angka dari 1 sampai 10 dalam bahasa Arab;

(2) الأيام (al-ayyam) yaitu pengenalan hari-hari dalam bahasa Arab;

(3) (al-fawakih) yaitu pengenalan buah-buahan dalam bahasa Arab;

(4) (al-alwan) yaitu pengenalan warna-warna dalam bahasa Arab.

Semua tema-tema di atas sebagaimana dimaksudkan dalam kompetensi dasar (KD) pada kurikulum 2013 sepenuhnya sama dengan tema yang ada pada buku Bahasa Arab kelas I MI ini. 


\section{c) Ketercernaan Materi}

Ketercernaan materi artinya kemudahan materi untuk dicerna dan difahami oleh pengguna. Dalam hal ini sedikitnya terdapat enam poin yang harus terdapat dalam buku Bahasa Arab ini sehingga konsep ketercernaan ini terpenuhi:

(1) Pemaparan yang Logis

Buku Bahasa Arab ini menggunakan sistematika sebagai berikut:

Ayo Mengamati!

Ayo Membaca!

Ayo Membaca Gambar!

Ayo Menyimak!

Ayo Latihan!

Masing-masing dari sub bahasan ini sekaligus menjadi langkah-langkah dalam pembelajaran yang disesuaikan dengan pendekatan saintifik sebagaimana dianut oleh kurikulum 2013.

Dalam sub bab Ayo Mengamati, berisi satu gambar atau dua gambar. Gambar yang ditampilkan adalah gambar yang memiliki keterkaitan sangat erat dengan tema yang akan dipelajari.

Dalam sub bab Ayo Membaca, berisi kosakata yang sesuai tema. Ada 7 sampai 10 kosakata baru yang dipaparkan dalam sub ini.

Sementara pada sub bab Ayo Membaca Gambar, merupakan kelanjutan dari membaca kosakata dengan diperkuat gambar yang sesungguhnya adalah makna dari masing-masing kosakata tersebut.

Sedangkan pada sub bab Ayo Menyimak, terdiri dari susunan kosakata yang sudah dipelajari pada sub bab sebelumnya dengan susunan yang telah diacak kemudian diberi perintah: "Tunjuklah (dengan alat petunjuk) kata yang sesuai dengan ucapan yang diperdengarkan, lalu ucapkan!”.

Pada sub bab Ayo Latihan, buku ini menyajikan latihan penguasaan materi sebelumnya dengan empat (4) macam model latihan. Jenis latihan tersebut seperti menghubungkan kata yang sama, menghubungkan kata dengan gambar, memilih gambar sesuai kata yang ditampilkan, dan menyebutkan kata Arab dari gambar yang ditampilkan.

Dari gambaran sistematika di atas, peneliti menemukan pemaparan yang logis dalam buku ini. Hal ini di samping sesuai dengan tahapan pendekatan saintifik sesuai peraturan menteri pendidikan dan kebudayaan Republik Indonesia nomor 81A tahun 2013 tentang Implementasi Kurikulum Pedoman Umum Pembelajaran, disebutkan bahwa proses pembelajaran terdiri atas lima pengalaman belajar pokok yaitu: mengamati; menanya; mengumpulkan informasi; mengasosiasi; dan mengkomunikasikan.

Selain itu, pemilihan kosakata dan jumlah kosakata baru yang disajikan sebanyak 7 sampai 10 kata baru yang dekat dengan kehidupan murid untuk tingkat kelas I, peneliti melihat itu sangat wajar. Hal itu mengacu pada teori pemilihan dan penggunaan kosakata yang disajikan Dr. Nashir Abdullah al-Ghali bersama Dr. Abdul Hamid Abdullah ( الغالى Y.. T, الم \&).

\section{d) Penyajian Materi yang Urut}

Penyajian materi dalam buku ini sudah peneliti paparkan di atas. Dari sistematika yang disajikan, yaitu: Ayo Mengamati!, Ayo Membaca!, Ayo Membaca Gambar!, Ayo Menyimak!, dan Ayo Latihan! Menggambarkan urutan pembahasan yang runut sesuai 
konsep K-13 dengan pendekatan saintifik, yaitu: mengamati; menanya; mengumpulkan informasi; mengasosiasi; dan mengkomunikasikan.

\section{e) Ada Contoh dan Ilustrasi yang Memudahkan Pemahaman}

Pada buku Bahasa Arab ini diberikan contoh dan ilustrasi yang berupa gambar dan petunjuk yang jelas. Masing-masing kata yang disajikan diberikan ilustrasi gambar yang relevan. Hal itu dapat peneliti temukan dalam setiap tema terutama pada sub bab ayo membaca gambar.

Pemberian ilustrasi gambar dan contoh dalam pemberian latihan yang terdapat daalam buku ini menurut peneliti sudah tepat, sesuai teori psikologi media pembelajaran sebagaimana dikemukakan oleh Ahmad Manshur yang mengatakan (عبد المجيد سيد أحمد رis, t.t.):

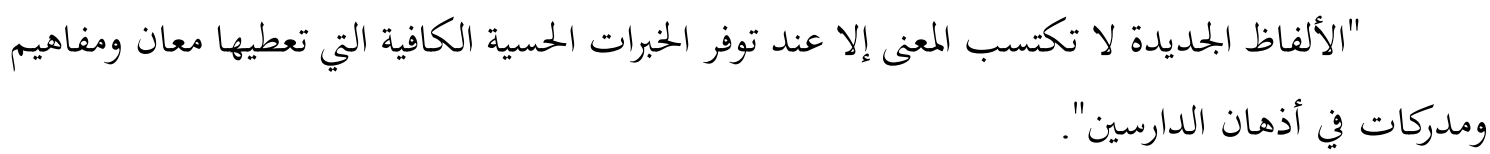

("Kata-kata baru tidak dipahami maknanya kecuali ketika sudah ditemukan melalui pengalaman yang bersifat indrawi yang dapat memberikan makna dan pemahaman yang kuat dalam otak pelajar”.)

\section{f) Alat Bantu yang Memudahkan}

Alat bantu yang memudahkan dalam penulisan buku pelajaran seperti buku Bahasa Arab ini dapat berupa kata-kata instruktif yang menjadi petunjuk dalam setiap langkah serta setiap sub bahasannya. Terlebih lagi, buku Bahasa Arab ini dilengkapi dengan buku guru yang menjadi alat bantu bagi guru untuk menjalankan proses pembelajaran di kelas.

Menurut peneliti, buku Bahasa Arab untuk kelas I MI ini sudah memiliki alat bantu yang baik, yaitu keberadaan buku khusus guru dan sajian kata-kata instruktif dalam setiap bab dan sub bab pembahasannya.

\section{g) Format yang Tertib dan Konsisten}

Adapun format dan sistematika yang ada dalam buku tersebut berjalan secara konsisten dalam setiap tema, yaitu diawali dengan penampilan gambar yang sesuai dengan tema/judul, lalu diberikan kosakata yang mudah dan relevan, lalu diberikan ilustrasi gambar pada setiap kata yang disajikan, setelah itu pelajaran menyimak dan yang terakhir adalah latihan.

Format seperti ini telah peneliti temukan dalam setiap bab, dari semester I sampai semester II. Dengan artian, penyajian format semacam ini dapat dikatakan tertib dan konsisten.

\section{h) Penjelasan tentang Relevansi dan Manfaat Bahan Ajar}

Nah pada poin ini peneliti tidak menemukan penjelasan relevansi dan manfaat bahan ajar pada masing-masing bab. Namun demikian, penjelasan itu barangkali disatukan dengan kata pengantar yang disampaikan oleh Direktur Jenderal Pendidikan Islam.

Tetapi seyogyanya, buku pelajaran yang baik memuat tujuan dan target secara khusus dalam setiap bab/dars yang akan diajarkan. Sehingga manfaat dan relevansi isi dari materi yang tersaji dapat terukur dengan tujuan yang jelas. 


\section{i) Penggunaan Bahasa}

Penggunaan bahasa pengantar buku menggunakan bahasa Indonesia, sehingga memudahkan kepada siswa dan guru dalam memahami perintah instruksional yang terdapat di dalam buku Bahasa Arab ini.

Namun yang paling penting dalam teori penggunaan bahasa dalam penyususnan buku Bahasa Arab adalah bahasa konten / isi dari bahasa Arab yang diajarkan kepada siswa dalam buku tersebut. Sehingga, dari buku Bahasa Arab tersebut siswa dapat mengetahui dan mempraktikkan materi bahasa Arab yang disajikan dalam buku.

Nah, dalam hal ini buku Bahasa Arab untuk kelas I MI ini menggunakan Bahasa Arab Fusha (اللغة العربية الفصحى). Di mana penggunaan bahasa Arab fusha ini adalah sesuai dengan teori penyusunan buku pembelajaran Bahasa Arab sebagaimana diutarakan oleh Dr. Nashir dan Dr. Abd Hamid ( r. . T T, الغالى \& الملك).

\section{j) Perwajahan/Pengemasan}

Perwajahan buku berhubungan dengan penataan letak informasi dalam satu halaman cetak dan pengemasan dalam paket buku pelajaran.

Dalam hal ini buku Bahasa Arab siswa dan guru yang diterbitkan oleh Kementerian Agama Republik Indonesia ini telah didesain sedemikian rupa sehingga perwajahan dari buku nampak elok di mata dan memotivasi pelajar untuk giat belajar karena tata letak yang apik.

Pada poin ini peneliti melihat bahwa keberadaan buku ajar Bahasa Arab ini sudah cukup memenuhi standar.

\section{k) Ilustrasi}

Ilustrasi digunakan untuk menjadikan buku lebih menarik, memotivasi dan membantu pemahaman siswa terhadap isi pesan. Dalam hal ini, ilustrasi bisa berupa table, diagram, grafik, kartun, foto, sketsa, gambar, symbol dan skema.

Pada poin ini, peneliti telah mengurainya pada pembahasan analisis ketercernaan materi pada sub bahasan sebelumnya. Ilustrasi pada buku ini menjadi satu kesatuan dengan ilustrasi materi bahasa Arab yang diuraikan pada setiap halaman buku ini.

Di samping itu, ilustrasi pada setiap halaman dari buku ini juga telah memenuhi unsure tata letak dan layout dari sebuah buku yang layak untuk dijadikan pelajaran pada murid-murid, terutama untuk tingkat kelas I Madrasah Ibtidaiyah.

Oleh karena itu, peneliti menganggap bahwa buku ini telah memenuhi kebutuhan akan ilustrasi pada setiap buku pembelajaran.

Kutipan buku tentang ilustrasi gambar pada masing-masing kata 

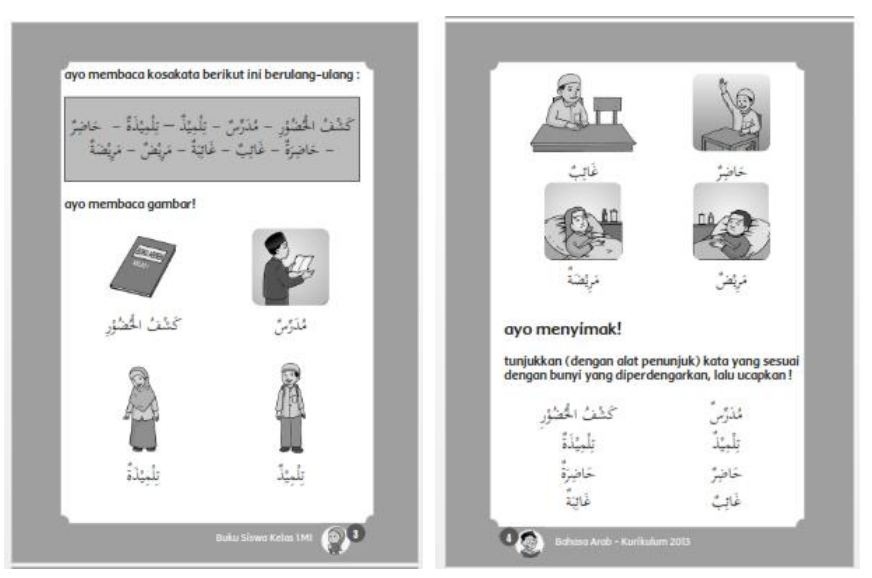

\section{l) Kelengkapan Komponen}

Kelengkapan komponen berkaitan dengan paket buku pelajaran yang terdiri dari komponen utama, komponen pelengkap dan komponen evaluasi hasil pelajaran.

Dari ketiga komponen yang dibutuhkan dalam sebuah buku pelajaran sebagaimana disinggung tadi, buku Bahasa Arab ini dapat dikatagorikan lengkap. Buku ini memiliki komponen utama yaitu materi bahasa Arab yang tercakup dalam setiap tema dan sub pembahasannya, sebagaimana telah peneliti urai sebelumnya.

Dari segi komponen pelengkap, buku ini telah dilengkapi dengan buku guru yang menjadi pedoman guru dalam mengajarkan materi yang tercantum dalam buku siswa. Di samping itu, buku Bahasa Arab siswa ini dilengkapi dengan daftar ini dan perintah instruksional dalam setiap pembahasannya.

Sedangkan komponen evaluasi terdapat di akhir setiap semester. Sehingga buku ini hanya memuat dua komponen evaluasi, yaitu akhir semester I dan di akhir semester II. Selain dua evaluasi tersebut, sesungguhnya di akhir setiap pembahasan terdapat lembar latihan.

\section{Seleksi, Gradasi, Presentasi dan Repetisi Buku}

Berikut peneliti paparkan analisis yang berhubungan dengan tahapan penyajian materi bahasa Arab dalam buku ajar Bahasa Arab Pendekatan Saintifik untuk kelas I Madrasah Ibtidaiyah yang diterbitkan oleh Kementerian Agama Republik Indonesia tahun 2014. Dalam hal ini peneliti menggunakan teori Mackey yang meliputi: Seleksi; Gradasi; Presentasi; dan Repetisi (Nurhadi, t.t.).

\section{a) Seleksi (Pemilihan Materi)}

Tahap seleksi dianggap penting dalam pengembangan dan analisis materi pengajaran bahasa. Tingkat kemahiran siswa juga mempengaruhi seleksi materi yang akan diajarkan. Tingkat pemahaman dasar dan menengah tentu berbeda dengan tingkat pemahaman atas. Pengajaran bahasa yang baik ditentukan oleh prosedur yang baik pula.

Mackey mengajukan beberapa prinsip yang melandasi seleksi, yaitu:

(1) Tujuan Belajar:

Proses seleksi yang pertama adalah mengetahui tujuan pembelajaran. Dalam pemilihan materi bahasa Arab pada buku ini telah mengacu pada proses seleksi tahap pertama ini. Hal itu dibuktikan dengan kesesuaian tema dengan tujuan konseptual yang terdapat dalam KI dan KD kurikulum 2013 yang diwakili oleh PMA nomor 0912 tahun 2013. 
Namun sayangnya, tujuan pembelajaran dalam masing-masing bab/dars tidak ditemukan pada buku siswa tetapi disebutkan dalam buku guru. Barangkali penyebutan tujuan pembelajaran yang dimuat dalam buku guru dianggap sudah cukup memadai. Padahal, kebutuhannya berbeda; buku guru untuk diketahui oleh guru, sedangkan buku siswa untuk diketahui oleh siswa dan atau wali siswa.

(2) Tingkat Kemampuan Siswa:

Pemilihan materi selanjutnya didasarkan pada tingkat kemampuan siswa, dalam hal siswa kelas I Madrasah Ibtidaiyah setara kelas I Sekolah Dasar (SD). Di mana siswa pada tingkat ini merupakan tingkatan paling dasar (basic). Sehingga materi yang dipilih dari tema-tema pilihan tersebut juga harus sangat mendasar. Karena materi bahasa Arab ini terus berkelanjutan sampai tingkat berikutnya dan jenjang yang lebih tinggi, maka pemilihan materi bahasa Arab harus pula memperhatikan asas gradasi.

Dalam buku Bahasa Arab ini, peneliti melihat bahwa seleksi materi yang didasarkan pada tingkat kemampuan siswa sudah terpenuhi. Salah satu buktinya adalah ما اسمك؟ tidak adanya dialog bahasa Arab yang panjang, kecuali pertanyaan singkat seperti dan هذا كتاب. Selain itu hanyalah pengenalan kosakata dasar yang disesuaikan dengan tema. Jumlah kata baru yang menjadi pokok materi pada setiap temanya hanya berjumlah 7 sampai 10 kata.

(3) Lama Waktu Belajar

Seleksi materi berdasarkan lama waktu belajar ini juga penting, mengingat waktu belajar di sekolah sangat terbatas. Sebagaimana diatur dalam peraturan menteri pendidikan nasional (Permendiknas) nomor 22 tahun 2006 tentang standar isi yang mengacu kepada Peraturan Pemerintah Nomor 19 tahun 2005 tentang Standar Nasional Pendidikan, disebutkan bahwa beban belajar kegiatan tatap muka per jam pembelajaran pada masing-masing satuan pendidikan ditetapkan sebagai berikut:

(a) SD/MI/SDLB berlangsung selama 35 menit;

(b) SMP/MTs/SMPLB berlangsung selama 40 menit;

(c) SMA/MA/SMALB/SMK/MAK berlangsung selama 45 menit.

Maka dengan demikian, jumlah materi dan banyaknya latihan perlu diseleksi berdasarkan ketersedian waktu tersebut. Sementara materi Bahasa Arab untuk kelas I MI memiliki alokasi waktu $2 \times 35$ menit $=70$ menit $(1.10$ jam $)$ dalam setiap minggu. Sehingga dalam satu semester yang mempunyai 20 sampai 22 minggu, maka ketersediaan waktu menjadi 70 menit x 20/22 minggu $=1400$ menit $(23,3$ jam $)$. Dengan demikian, apabila dalam satu semester terdapat empat (4) tema pembahasan, maka masing-masing tema mempunyai alokasi waktu lima kali tatap muka dengan durasi waktu masing-masing 70 menit $(2 \times 35$ menit).

Dari alokasi waktu yang tersedia inilah, peneliti melihat bahwa materi yang terkandung dalam buku Bahasa Arab untuk kelas I MI ini cukup memadai. Karena masing-masing tema dibagi menjadi 5 bagian, yaitu: Ayo Mengamati!, Ayo Membaca!, Ayo Membaca Gambar!, Ayo Menyimak!, dan Ayo Latihan! Dan muatan materi pada masing-masing bagian sangat mungkin dicapai dalam durasi waktu 70 menit.

(4) Pilihan Tipe Bahasa yang Dipelajari

Pilihan tipe bahasa yang dipelajari ini sudah peneliti uraikan pada pembahasan sebelumnya. Yaitu, bahasa Arab fusha yang menjadi pilihan dari materi buku Bahasa Arab ini adalah bagian dari seleksi materi yang sudah tepat.

(5) Factor Kemungkinan Dipelajari 
Pemilihan kata-kata bahasa Arab yang ditampilkan dalam buku ini sudah memenuhi standar tentang "kemungkinan untuk dipelajari". Hal itu terlihat dari pilihan kata yang popular digunakan dan termasuk dalam katagori fasih.

Selain itu, penggunaan ungkapan bahasa Arab yang terdapat dalam buku ini juga ungkapan yang fasih, tidak memuat ungkapan "ammiyah" yang melenceng dari kaidah gramatikal bahasa Arab.

\section{b) Gradasi (Pengurutan)}

Setelah selesai tentang analisis "seleksi" terhadap buku Bahasa Arab ini, kali ini peneliti akan menganalisis konsep "gradasi" dalam materi buku tersebut. Gradasi adalah penyusunan materi secara bertahap; mulai dari materi yang mudah kemudian terus secara bertahap kepada materi yang lebih sulit sampai akhirnya kepada materi yang sulit. Karena materi itu tidak mungkin disampaikan sekaligus.

Sebuah buku pelajaran yang menggunakan konsep gradasi, akan memudahkan siswanya untuk lebih memahami isi dari buku tersebut. Dalam hal ini, Mackey mengajukan dua syarat penting agar buku dapat disebut memenuhi konsep gradasi, yatiu: pengelompokan (grouping) dan pengurutan (gradation).

Dalam pengelompokan (grouping) yang harus diperhatikan seperti keseragaman, kekontrasan dan keperalelan. Sedangkan dalam pengurutan (gradation) didasarkan pada prinsip psikologi, seperti dimulai dari yang pendek terus yang lebih panjang. Diawali dengan yang mudah terus yang lebih sulit dan begitu seterusnya.

Dari teori Mackey ini, peneliti menemukan bahwa materi yang terkandung dalam buku Bahasa Arab ini telah melakukan pengelompokan (grouping) kata-kata yang sesuai dengan tema. Masing-masing tema terdapat 7 sampai 10 kata yang popular dan mudah diaplikasikan.

Sedangkan pengurutan (gradation) dalam masing-masing tema terlihat dari menyajian materi, yaitu mulai dari materi kosakata, lalu kata dengan maknanya yang diwakili oleh gambar, lalu menuju ungkapan-ungkapan pendek yang merupakan aplikasi dari penggunaan kata-kata tersebut, baru kemudian latihan.

\section{c) Presentasi}

Tahap selanjutnya adalah konsep presentasi, yaitu suatu cara mengkomunikasikan materi kepada pembelajar bahasa dengan menunjukkan apa yang ada dalam halamanhalaman buku pelajaran tersebut.

Ada bermacam-macam model presentasi, seperti yang diungkapkan Mackey terdapat empat macam:

(1) Prosedur deferensiasi, yaitu menjelaskan sebuah kaidah dengan menerjemahkan penjelasan dalam bahasa nasional/daerah para pembelajar.

(2) Prosedur ostensive, yaitu menggunakan objek, tindakan dan situasi dalam menjelaskan.

(3) Prosedur pictorial, yaitu penggunaan gambar-gambar.

(4) Prosedur kontekstual, yaitu penjelasan yang bersifat abstrak yang meliputi definisi, anumerasi, subtitusi, methapor, opposisi, dan multiple konteks.

Dari empat model presentasi ini, prosedur pictorial merupakan model presentasi yang dipakai dalam buku Bahasa Arab ini. Di mana penjelasan makna dari materi bahasa Arab yang berupa kosakata dan ungkapan-ungkapan singkat bahasa Arab dijelaskan dalam penggunaan gambar-gambar. 


\section{d) Repetisi (pengulangan)}

Repetisi merupakan langkah yang ditempuh untuk materi yang disajikan dapat dicerna dan diinternalisasikan oleh pembelajar bahasa menjadi kemampuan bahasa yang siap pakai.

Teknik penajaman (repetisi) yang paling lazim digunakan adalah latihan yang bersifat reseftif dan produktif. Latihan yang bersifat reseptif adalah latihan menyimak, mendengarkan dan membaca.

Dalam buku Bahasa Arab ini, peneliti juga telah menemukan adanya repetisi dalam setiap tema atau bab pembahasannya. Bentuk repetisi yang dianut dalam buku ini terdapat dua jenis; yaitu model latihan yang dimuat setiap akhir bab, dan model evaluasi yang dimuat di akhir semester.

\section{KESIMPULAN}

Dari hasil analisis terhadap content Buku Ajar Bahasa Arab (Pendekatan Saintifik Kurikulum 2013) Kelas I Madrasah Ibtidaiyah terbitan Kementerian Agama Republik Indonesia tahun 2014 ini, peneliti memiliki kesimpulan bahwa buku ini layak dan cocok untuk digunakan oleh peserta didik tingkat sekolah dasar (madrasah ibtidaiyah) kelas I sebagai bahan ajar yang dapat menunjang terrcapainya tujuan pembelajaran bahasa Arab. Ada tiga kesimpulan dari penelitian ini:

1. Merujuk pada faktor-faktor yang harus diperhatikan dalam penyusunan buku pelajaran sebagaimana dikemukakan M. Abdul Hamid dalam buku "Pembelajaran Bahasa Arab: Pendekatan, Metode, Strategi, Materi dan Media" yaitu meliputi: 1). Isi Buku; 2). Ketepatan Cakupan; 3). Ketercernaan Materi; 4). Penggunaan Bahasa; 5). Perwajahan/Pengemasan; 6). Ilustrasi; dan 7). Kelengkapan Komponen, maka dari segi isi (content) buku ini telah memenuhi standar buku pelajaran yang baik dalam semua factor tadi. Hanya saja, pada factor ketercernaan materi khususnya dalam poin "penjelasan tentang relevansi dan manfaat bahan ajar", buku siswa Bahasa Arab ini tidak memuat tujuan pembelajaran dalam setia bab/tema yang dibahas. Ini barangkali dicukupkan pada penjabaran tujuan pembelajaran yang telah dimuat dalam buku guru sebagai komponen pelengkap buku ajar, padahal kepentingan poin ini berbeda antara buku guru dan buku siswa mengingat sasarannya yang berbeda pula; buku guru untuk diketahui guru, sedangkan buku siswa untuk dipahami siswa dan atau wali siswa.

2. Selain itu, dari aspek kesesuaian content buku Bahasa Arab ini dengan muatan kurikulum 2013 (K-13) sebagai landasan formal kurikulum pendidikan di Indonesia, buku ini dalam hasil analisis peneliti juga telah memenuhi tuntutan kurikulum pemerintah yang mengacu pada Peraturan Menteri Agama (PMA) Nomor 0912 Tahun 2013.

Sedangkan dalam aspek tahapan penyajian materi bahasa Arab yang meliputi: 1). Seleksi; 2). Gradasi; 3). Presentasi; dan 4). Repetisi, buku ini juga sudah sesuai dengan teori Mackey yang telah dipaparkan oleh Nurhadi dalam buku "Tata Bahasa Pendidikan (Landasan Penyusunan Buku Pelajaran Bahasa)". 


\section{DAFTAR RUJUKAN}

Indonesia, L. P. M. A. R. (t.t.). Nomor 912 tahun 2013 tentang Kurikulum Madrasah 2013 mata Pelajaran PAI dan Bhs. Arab.

Indonesia, R. (t.t.). Peraturan Menteri Pendidikan Nasional RI Nomor 24 Tahun 2006 Tentang. Pelaksanaan Peraturan Menteri Pendidikan Nasional Nomor 22 Tahun 2006 Tentang Standar Isi Untuk Satuan Pendidikan Dasar Dan Menengah dan Peraturan Menteri Pendidikan Nasional Nomor 23 Tahun 2006 Tentang Standar Kompetensi Lulusan Untuk Satuan Pendidikan Dasar Dan Menengah.

Kementerian Agama Republik Indonesia. (2014). Bahasa Arab: Buku Guru: MI -1 (1 ed.). Jakarta: Direktorat Pendidikan Madrasah.

Lexy, J. M. (2002). Metode penelitian kualitatif. Bandung: Rosda Karya.

Mujib, F. (2013). Pengembangan Bahan Ajar Buku Teks Pelajaran Bahasa Arab Tingkat MTs Kelas VII Dan VIII Di Penerbit PT Tiga Serangkai Mandiri Solo $(\mathrm{PhD}$ Thesis). Tesis Magister Pendidikan Islam., Yogyakarta: Perpustakaan PPs. UIN Sunan Kalijaga.

Muslich, M. (2010). Text book writing: Dasar-dasar pemahaman, penulisan, dan pemakaian buku teks. Jogjakarta: Ar-Ruzz Media, 52, 47-52.

Nurhadi, T. B. P. (t.t.). Landasan Penyusunan Buku Pelajaran Bahasa. Semarang: IKIP Semarang Press, $t$.

Pd, T. M. (2010). Pengantar penelitian pendidikan bagi pengembangan profesi pendidikan \& tenaga kependidikan. Jakarta: Kencana prenada media group.

Pendidikan, P. M. (2013). Peraturan Menteri Pendidikan dan Kebudayaan Republik Indonesia Nomor 81A Tahun 2013 Tentang Implementasi Kurikulum. Jakarta: Pemerintah Republik Indonesia.

Pendidikan, P. M., \& Nomor, K. (t.t.). 160 Tahun 2014 tentang Pemberlakukan Kurikulum Tahun 2006 dan Kurikulum 2013. 2014. Jakarta: Menteri Pendidikan dan Kebudayaan Republik Indonesia.

Pohan, R. (2007). Metodologi Penelitian Pendidikan. Yogyakarta, Lanarka.

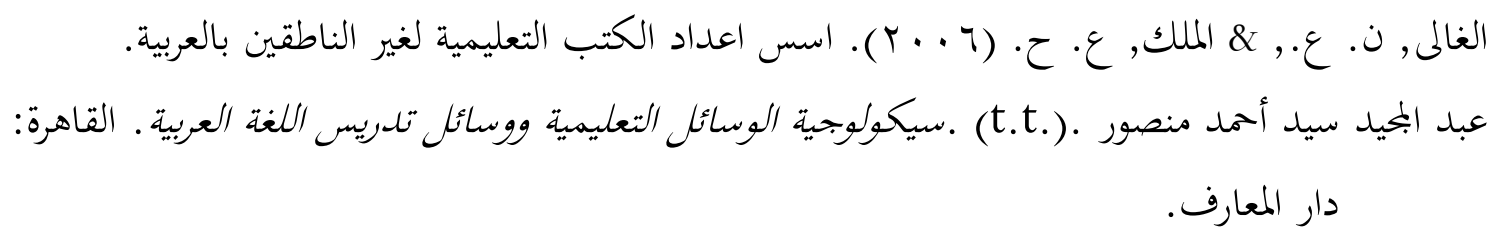

Vol. 1 No. 1 / April 2018

IJAZ ARABI homepage: http://ejournal.uin-malang.ac.id/index.php/ijazarabi 